\title{
Article
}

Doi 10.5943/sif/1/1/14

Copyright @ Mushroom Research Foundation 2016

\section{Two new records of hydnoid fungi from the Western Ghats of India}

\author{
Karun $\mathrm{NC}^{1}$ and Sridhar $\mathrm{KR}^{1}$ \\ ${ }^{1}$ Department of Biosciences, Mangalore University, Mangalagangotri, Mangalore 574 199, Karnataka, India
}

Karun NC, Sridhar KR 2016 - Two new records of hydnoid fungi from the Western Ghats of India. Studies in Fungi 1(1), 135-141, Doi 10.5943/sif/1/1/14

\begin{abstract}
During inventory of macrofungi in the forests of Western Ghats, two hitherto unrecorded rare hydnoid taxa, Gyrodontium sacchari (Spreng.) Hjortstam (Agaricomycetes, Boletales, Coniophoraceae) and Hericium cirrhatum (Pers.) Nikol. (Agaricomycetes, Russulales, Hariciaceae) were recovered on decaying wood. Both are reported from North-Eastern India, thus the present report constitutes the first report for the Western Ghats of India. This communication embodies brief systematic accounts with illustrations, substrates, distributions and economic value of these hydnoid fungi.
\end{abstract}

Key words - forest - Gyrodontium sacchari - Hericium cirrhatum - macrofungi - wood

\section{Introduction}

The hydnoid fungi are commonly known as tooth fungi as they produce spores on pegs or spines or tooth-like projections underneath the fruit body. Index Fungorum (2016) documented nearly 900 species of hydnoid fungi worldwide. Gyrodontium sacchari has been originally reported from Guadeloupe as Hydnum benningsii Bers. a generic type species in 1890. Subsequently it was recorded from Argentina, Bahia State, Belize, Brazil, Costa Rica, Cuba, Ecuador, French Guiana, Mexico and Panama (see Robledo et al. 2014). Hembrom et al. (2014) recorded this fungus for the first time in India in the West Bengal during 2013. The hydnoid nature of hymenophore of the genus Hericium was shown by Persoon (1794) and described as Hydnum cirrhatum. Nikolajeva (1950) transferred this species to the genus Hericium. The genus Hericium is of particular interest due to peculiarity in morphology of fruit body possessing woolly surface. Because of specific woolly texture, some of them are commonly called bear's head mushroom (H. americanum), monkey's head mushroom (H. cirrhatum) and lion's mane or goat's beard mushroom (H. erinaceus). Their common names is also due to nature spines like coral-spine mushroom (H. coralloides), spine-face or tiered-tooth mushroom $(H$. cirrhatum). The present study provides systematic account of Gyrodontium sacchari and Hericium cirrhatum recovered from the Western Ghats with notes on their distribution, edibility and economic value.

\section{Systematic account}

Gyrodontium sacchari (Spreng.) Hjortstam, 1995, Mycotaxon 54: 186

Fig. 1A-F; 2A-F

Syn.: Hydnum sacchari Spreng., 1820, K. Sevenska Vetensk-Acad. Handl. 46: 51.

Description - Large creamy-brown brackets with spongy to puffy upper surface on eruption (Fig. 1A and B) possessing fertile cylindrical pegs underneath (Fig. 2B, C and D). Solitary or in 

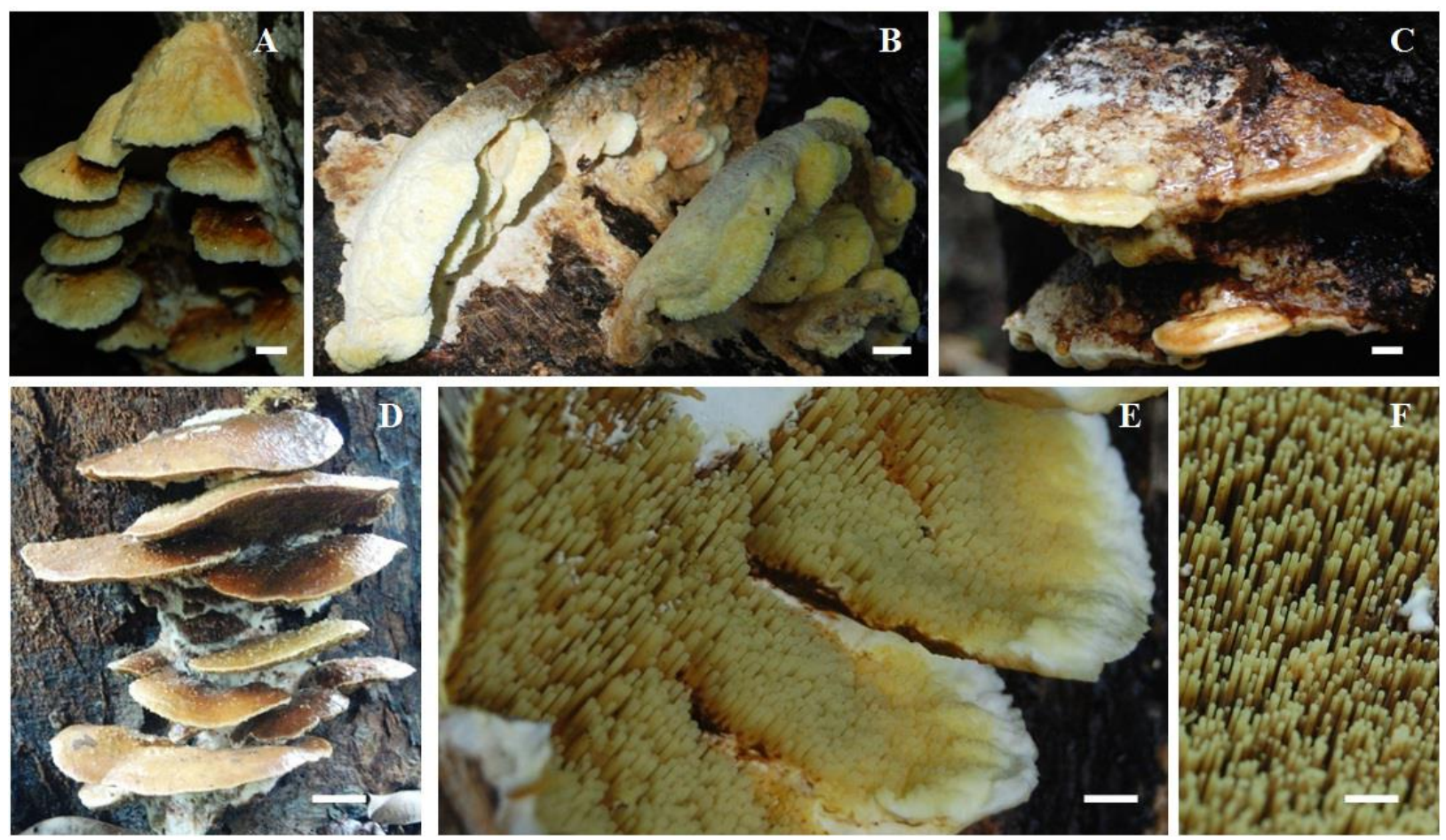

Fig. 1 - Gyrodontium sacchari. A-B. developing basidiomata. C-D. solitary and tuft of maturing basidiomata. E-F. side view and tips of developing pegs underneath basidiomata. Scale bar $=1 \mathrm{~cm}$.

tufts (Fig. 1C and D), annual, lignicolous, rare, odor mealy or almond-like, taste not distinctive, edible based on tribal knowledge and measures 3.2-20.2 cm diam. $\times 0.5-2.3 \mathrm{~cm}$ thick.

Basidiomata initially small, drooping, dirty-white to yellowish-cream or yellowish-brown on eruption (Fig. 1A and B), becoming irregular to bracket-shaped to lobed or tufted with wavy margin (Fig. 1D and 2A). Upper surface is grayish-brown/smoky-brown/creamy-brown/orangebrown (Fig. 1C, 2A and 2E), slimy to smooth, spongy to puffy, fleshy when moist, smoky-grey on drying, warty to rough and leathery. The lower part initially yellowish-green (Fig. 1E) or greenishbrown (Fig. 1F) and becoming brownish-green on maturity (Fig. 2B, C and D). Fertile hymenium bears cylindrical, smooth, thick or thin, soft, blunt pegs (Fig. 2D), 5-16 mm tall $\times 1 \mathrm{~mm}$ thick, crowded and spread over the under surface (Fig. 2B). Sessile or occasionally knob-like with short stem, flesh creamish to greenish-brown and soft. Basidia elongated and 2-4 spored. Spores oval to ellipsoidal, smooth, greenish-yellow or yellowish-brown and measures 3.4-4.7 $\times 2.6-3 \mu \mathrm{m}$ (Fig. $2 \mathrm{~F})$.

Substrate - On the rotting fallen trunk and standing dead palm Caryota urens in Sampaje Reserve Forest of the Western Ghats $\left(12^{\circ} 28^{\prime} \mathrm{N}, 7^{\circ} 37^{\prime} \mathrm{E} ; 608 \mathrm{~m}\right.$ asl) (July 31, 2013) (Table 1). On standing dead $C$. urens and base of live Terminalia catappa tree in Arboretum of Mangalore University Campus, Konaje (12 $48^{\prime} \mathrm{N}, 74^{\circ} 55^{\prime} \mathrm{E} ; 87.2 \mathrm{~m}$ asl) (September 20, 2015) (Table 1).

Distribution - It was first reported from India in the Acharya Jagadish Chandra Bose Indian Botanical Garden, West Bengal during June 26th, 2013 (Hembrom et al. 2014). The present study from the Western Ghats and subsequently from the west coast of India constitutes the second report (Table 2). It has a wide distribution in different ecosystems in five continents specifically from the Argentina, Bahia State, Belize, Brazil, Caribbean, Costa Rica, Cuba, Ecuador, Ethiopia, French Guiana, Guadeloupe, Mexico, Panama, Tanzania and Zimbabwe (Valenzuela et al. 2012, Robledo et al. 2014). It has been traced mainly in the old-growth forests (especially on fallen dead angiosperm wood and in base of living trees), however in Brazil it was reported inside a tree hole of a living tree (Robledo et al. 2014). Interestingly, it was also found associated with monocots like fallen palm in Belize and leaves of sugarcane in Guadeloupe (Valenzuela et al. 2012, Robledo et al. 2014). 

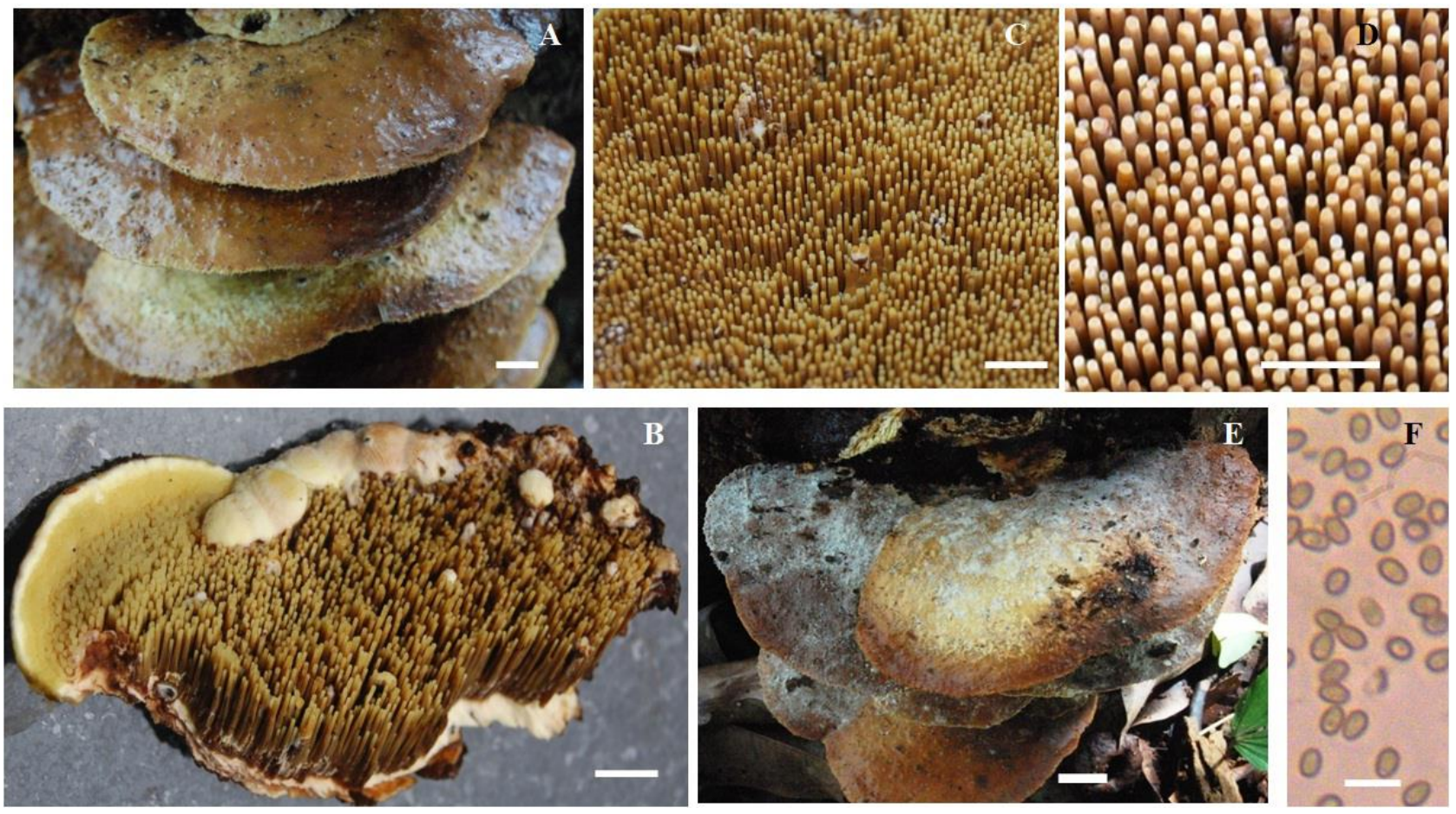

Fig. 2 - Gyrodontium sacchari. A. top view of mature basidiomata. B-D. details of pegs underneath mature basidiomata. E. basidiomata nearing decay. F. mature basidiospores. Scale bar: $\mathrm{A}-\mathrm{E}=1 \mathrm{~cm}, \mathrm{~F}=10 \mu \mathrm{m}$.

Table 1 Comparison of characteristics of Gyrodontium sacchari and Hercium cirrhatum

\begin{tabular}{|c|c|c|}
\hline & Gyrodontium sacchari & Hercium cirrhatum \\
\hline Nutritional mode & Wood and monocot stem saprotroph & Wood saprotroph \\
\hline Type of wood decay & White rot & White rot \\
\hline Host & $\begin{array}{l}\text { Wild palm Caryota urens (Western Ghats); } \\
\text { wild palm C. urens and Terminalia catappa } \\
\text { (west coast) }\end{array}$ & Endemic tree Euodia lunuankenda \\
\hline Substrate & $\begin{array}{l}\text { Fallen or standing dead dicot and monocot } \\
\text { trees }\end{array}$ & Live tree crevices \\
\hline Location & $\begin{array}{l}\text { Sampaje forest reserve (Western Ghats); } \\
\text { Arboretum (west coast) }\end{array}$ & Makutta forest reserve (Western Ghats) \\
\hline Fruiting season & $\begin{array}{l}\text { July-October (Western Ghats); August- } \\
\text { October (west coast) }\end{array}$ & July-August (Western Ghats) \\
\hline Optimum temperature & $\begin{array}{l}23-27^{\circ} \mathrm{C} \text { (Western Ghats); } 25.5-31.5^{\circ} \mathrm{C} \text { (west } \\
\text { coast) }\end{array}$ & $22-24^{\circ} \mathrm{C}$ (Western Ghats) \\
\hline Fruit body texture & Slimy and spongy to puffy & Hairy and fleshy \\
\hline Texture on drying & Leathery & Corky \\
\hline $\begin{array}{l}\text { Fertile region of } \\
\text { hymenophore }\end{array}$ & Greenish-brown crowded pegs & Whitish tiered teeth with pinkish tinge \\
\hline Spore color & Yellowish-brown & Hyaline \\
\hline $\begin{array}{l}\text { Edibility character and } \\
\text { odor }\end{array}$ & $\begin{array}{l}\text { Mealy or almond-like odor; Congregation of } \\
\text { fruit flies and ants }\end{array}$ & $\begin{array}{l}\text { Almond-like odor; Congregation of } \\
\text { fruit flies and ants }\end{array}$ \\
\hline Associated macrofungi & $\begin{array}{l}\text { Caryota urens: Lentinus spp., Pleurotus spp. } \\
\text { and Royporus spathulatus; Terminalia } \\
\text { catappa: Ganoderma spp. and Xylaria spp. }\end{array}$ & Pleurotus spp. \\
\hline
\end{tabular}



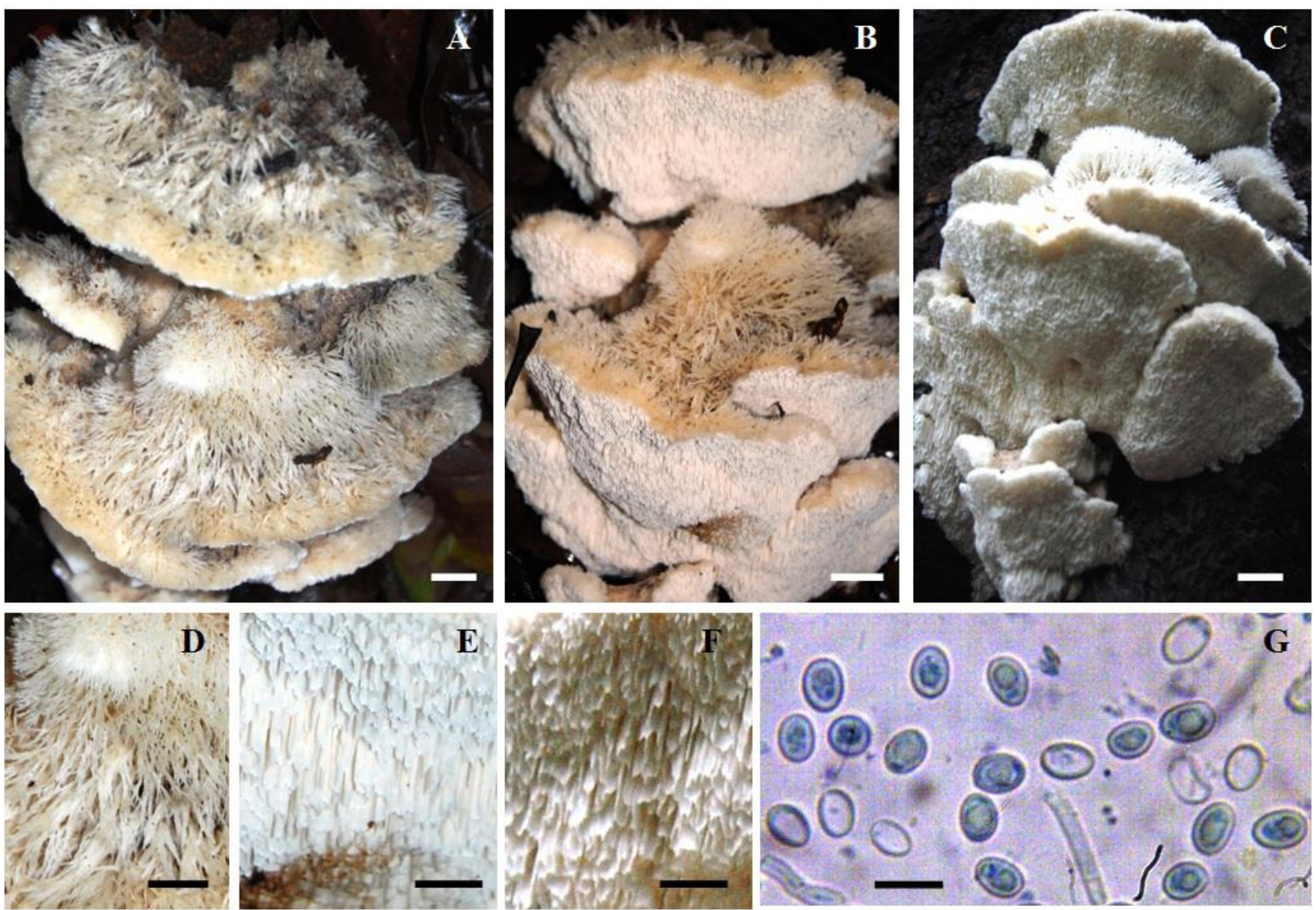

Fig. 3 - Hericium cirrhatum. A. top view of mature basidiomata with woolly nature. B. side view of mature basidiomata. C. lower view of mature basidiomata. D. details of woolly upper surface. E. and $F$. tiered teeth underneath basidiomata. $G$. mature basidiospores. Scale bar: $A-F=1 \mathrm{~cm}, \mathrm{G}=$ $10 \mu \mathrm{m}$.

Hericium cirrhatum (Pers.) Nikol. Acta Inst. Bot. Acad. Sci. USSR Plant Crypt., Fasc. II 6, 343 (1950)

Fig. 3A-G

Syn.: Hydnum cirrhatum Pers., 1794, Neues Mag. Bot. 1: 109; Hydnum corrugatum Fr., 1818, Observ. Mycol. (Havniae) 3: 269; Creolophus cirrhatus (Pers.) P. Karst., 1879, Meddn Soc. Fauna Flora Fenn. 5: 42; Steccherinum cirrhatum (Pers.) Teng, 1963, Thung-Kuo Ti Chen-Chan (Fungi of China): 763.

Description - Large white bracket-like caps with hairy-bristly upper surface and fertile flattened tiered teeth underneath. Solitary or in tufts (Fig. 3A, B and C), annual, lignicolous, rare, odor almond-like, taste not distinctive, edible and measures $2.2-10.9 \mathrm{~cm}$ diam. $\times 0.5-3.3 \mathrm{~cm}$ thick.

Basidiomata at first small pinkish-white eruption with fine hairs, on ageing becomes irregular to bracket-shaped, hairy and on maturity irregularly semicircular to lobed or bracket-like to shell-shaped with wavy margin (Fig. 3A, B and C). Upper surface sterile, light-brown to white, hairy-bristly and on ageing short-spined to warty (hairs get trimmed off due to heavy showers) (Fig. 3D). The lower pinkish-white fertile hymenium bears deadaleoid to lamellate, deeply incised, pointed, flattened teeth 5-18 mm tall, surface finely sulcate, tiered, crowded, spread over (Fig. E and F) and sometimes decurrent directly onto substrate. Sessile and laterally attached to substrate. Flesh whitish and soft. Basidia elongated, club-shaped and 2-4 spored. Spores whitish, smooth, oval and measures 9.8-11.2 × 7.2-8.2 $\mu \mathrm{m}$ (Fig. 3G).

Substrate - In the crevices of live Euodia lunuankenda tree trunk in Makutta reserve forest $\left(12^{\circ} 8^{\prime} \mathrm{N}, 7^{\circ} 47^{\prime} \mathrm{E} ; 897 \mathrm{~m}\right.$ asl) (July 24, 2012) (Table 1). 
Table 2 Distribution and substrate preference of Gyrodontium sacchari and Hericium spp. in India

\begin{tabular}{|c|c|c|c|}
\hline Species & Location & Substrate & Reference \\
\hline \multirow[t]{3}{*}{$\begin{array}{l}\text { Gyrodontium } \\
\text { sacchari }\end{array}$} & Botanical Garden, West Bengal & Dead log of Casuarina sp. & $\begin{array}{l}\text { Hembrom et al. } \\
\text { (2014) }\end{array}$ \\
\hline & $\begin{array}{l}\text { Sampaje, Western Ghats of } \\
\text { Karnataka }\end{array}$ & Dead stem of palm Caryota urens & Present study \\
\hline & Konaje, West coast of Karnataka & $\begin{array}{l}\text { Dead log of Terminalia catappa } \\
\text { tree }\end{array}$ & \\
\hline \multirow{3}{*}{$\begin{array}{l}\text { Hericium } \\
\text { bharengense } \\
\text { H. cirrhatum }\end{array}$} & Upper Bhareng, Sikkim & Logs of Tsuga dumosa & Das et al. (2011) \\
\hline & Yuksom, Sikkim & $\begin{array}{l}\text { Wood of Alnus nepalensis; Trunk } \\
\text { of Quercus sp. }\end{array}$ & $\begin{array}{l}\text { Das \& Sharma } \\
(2010)\end{array}$ \\
\hline & $\begin{array}{l}\text { Makutta, Western Ghats of } \\
\text { Karnataka }\end{array}$ & $\begin{array}{l}\text { Crevices of endemic tree Euodia } \\
\text { lunuankenda }\end{array}$ & Present study \\
\hline H. clathroides & Chamba, Himachal Pradesh & Dead tree of Quercus incane & $\begin{array}{l}\text { Thind \& Khara } \\
\text { (1975) }\end{array}$ \\
\hline \multirow[t]{4}{*}{ H. coralloides } & Darjeeling; West Bengal & $?$ & Berkeley (1851) \\
\hline & Mussoorie Hills, Uttarakhand & $?$ & $\begin{array}{l}\text { Bagchee et al. } \\
\text { (1954) }\end{array}$ \\
\hline & Pahalgam, Jammu-Kashmir & Log in coniferous forest & $\begin{array}{l}\text { Thind \& Khara } \\
\text { (1975) }\end{array}$ \\
\hline & Doda, Jammu- Kashmir & $\begin{array}{l}\text { Dead wood of Quercus } \\
\text { leucotrichophora }\end{array}$ & $\begin{array}{l}\text { Zutshi \& Gupta } \\
\text { (2013) }\end{array}$ \\
\hline \multirow[t]{6}{*}{ H. erinaceus } & Sikkim & $?$ & Berkeley (1851) \\
\hline & Mussoorie Hills, Uttarakhand & $?$ & $\begin{array}{l}\text { Bagchee et al. } \\
(1954)\end{array}$ \\
\hline & Narkanda, Simla & Log of coniferous tree & Thind \& Khara \\
\hline & Nainital, Uttarakhand & Base of Quercus incane & $(1975)$ \\
\hline & $\begin{array}{l}\text { Pauri, Uttarakhand; Shimla, } \\
\text { Himachal Pradesh }\end{array}$ & $\begin{array}{l}\text { Cracks of live but decaying } \\
\text { Quercus leucotrichophora }\end{array}$ & $\begin{array}{l}\text { Semwal et al. } \\
(2014)\end{array}$ \\
\hline & Western Ghats of Karnataka & Unknown tree canopy & $\begin{array}{l}\text { Karun \& Sridhar } \\
(2016)\end{array}$ \\
\hline H. yumthangense & Yumthang, Sikkim & Wood of Abies densa & Das et al. (2013) \\
\hline
\end{tabular}

Distribution - Six species of Hericium have been reported from the Indian Subcontinent on woody substrates mainly from the Himalayan region: Hericium bharengense K. Das, Stalpers \& Eberhardt; H. cirrhatum (Pers.) Nikol; H. clathroides (Pall.) Pers.; H. coralloides (Scop.) Pers.; H. erinaceus (Bull.) Pers.; H. yumthangense K. Das, Stalpers \& Stielow (Thind \& Khara 1975, Das \& Sharma 2009, Das et al. 2011, 2013, Zutshi \& Gupta 2013, Semwal et al. 2014) (Table 2). Hericium erinaceus was also known from the reserve forest of the Western Ghats during July 2012 (Karun \& Sridhar 2016). Hericium cirrhatum, H. coralloides and H. erinaceus were recorded from Asia, North America and Europe (see Boddy et al. 2011).

\section{Discussion}

Economic importance - Macrofungi are of promising interest due to their nutritional, therapeutic and bioactive components. Being mainly saprotrophic on wood, G. sacchari and $H$. cirrhatum are important especially in the old-growth forest ecosystem. Gyrodontium sacchari isolated from Pinus densiflora and Quercus sp. in Korea produced cellulase, xylanase and ligninase on agar media higher than many reference strains (Park et al. 2015). Fernando et al. (2015) has reported potent antioxidant activities of G. sacchari. Tribals of the Western Ghats (e.g. Kudia, Kuruba and Yerava) consume majority of macrofungi growing on C. urens (e.g. Pleurotus spp., Royporus spathulatus and Lentinus spp.) including G. sachari. In the present study, fruit fly (Drosophila) and ants were congregated on fruit bodies of G. sacchari. Based on tribal knowledge, such insect association of feeding indicates its edibility. Moreover, G. sacchari has pleasant mealy 
or almond odor, which is one of the main characteristic features of edible mushrooms in the Western Ghats.

Most of the young Hericium spp. are edible, however, there is no information about edibility of $H$. cirrhatum. Tribals of the Western Ghats designated this fungus as 'Karadi-Kum' (meaning: 'bear-head mushroom') with pleasant almond odor and it is delicacy for them. Besides edibility, Hericium spp. are also known for their therapeutic potential especially in stimulation or synthesis of nerve growth factor (NGF) and several health-promoting principles including those used in treatment of dementia (e.g. metabolites of $H$. erinaceus: Kawagishi and Zhuang 2008, Ma et al. 2010, Friedman 2015, Thongbai et al. 2015). It is also known that $H$. erinaceus possess polysaccharide belonging to $\beta$-glucan group showing potent antitumor activities (Seok et al. 2009).

Conservation - The Italian Botanical Society has proposed 23 species of macrofungi as rare and or endangered, which also encompass G. sacchari (IUCN, 1994). The wild palm supports growth of G. sacchari in the Western Ghats and west coast is Caryota urens (also called toddy or civet palm) used to extract toddy, they produce nuts similar to areca nut (Areca catechu) used for chewing during scarcity of nuts of $A$. catechu. Civet cats are known to raise their young ones in this palm and they are mainly dependent on pulp of fruits helping in seed as well as fungal dissemination. As Caryota urens serve as a potent host for G. sacchari, special care need to be exercised for its preservation. In the southwest coast of India, G. sacchari is widely associated with live as well as dead horticulture tree Terminalia catappa (almond tree).

Hericium coralloides and H. erinaceus are designated under 'vulnerable' (VU) category of Red List in many European countries (Boddy et al. 2011). Most of the Hericium spp. are edible and needs conservation measures during mass collection from wild. Being edible and medicinally versatile, several strategies and priorities of conservation of Hericium spp. have been offered by Boddy et al. (2011). In the Western Ghats, H. cirrhatum was found on the dead wood of endemic live trees of Euodia lunuankenda and this host is extensively used to manufacture plywood and matchsticks. Besides, $H$. cirrhatum was recovered on the tree canopy of unknown tree during July 2012 (Karun \& Sridhar 2016). It is likely Western Ghats harbor some more Hericium spp. warrants further exploration.

\section{Acknowledgements}

The authors are grateful to Mangalore University for permission to carry out this study in the Department of Biosciences. KRS acknowledges the award of UGC-BSR Faculty Fellowship by the University Grants Commission, New Delhi, India (Award \# F.18-1/64/2014/BSR). We appreciate help rendered by S. Mahadevakumar, Department of Botany, University of Mysore for rare literature; V. Ravikrishnan, Department of Biosciences for generating microscopic pictures.

\section{References}

Bagchee K, Puri YN, Bakshi BK. 1954 - Principal diseases and decays of oaks and other hard woods in India - II. Indian Phytopathology 7, 18-42.

Berkeley MJ. 1851. Decades of Fungi, Deca 35 (\# 341-350), Sikkim-Himalayan Fungi collected by Dr. Hooker. Hooker Journal of Botany 3, 167-172.

Boddy L, Crockatt ME, Ainsworth AM. 2011 - Ecology of Hericium cirrhatum, H. coralloides and H. erinaceus in the UK. Fungal Ecology 4, 163-173.

Das K, Sharma JR. 2010 - Hericium cirrhatum (Pers.) Nikol. A new record to Indian mycoflora. Kavaka 37-38, 17-19.

Das K, Stalpers J, Eberhardt U. 2011 - A new species of Hericium from Sikkim Himalaya (India). Cryptogamie, Mycologie 32, 285-293.

Das K, Stalpers JA, Stielow JB. 2013 - Two new species of hydnoid fungi from India. IMA Fungus 4, 359-369. 
Fernando D, Wijesundera R, Soysa P, De Silva D, Nanayakkara C. 2015 - Strong radical scavenging macrofungi from the dry zone forest reserves in Sri Lanka. Frontiers in Environmental Microbiology 1, 32-38.

Friedman M. 2015 - Chemistry, Nutrition, and health-promoting properties of Hericium erinaceus (Lion's Mane) mushroom fruiting bodies and mycelia and their bioactive compounds. Journal of Agricultural and Food Chemistry 63, 7108-7123.

Hembrom ME, Parihar A, Das K. 2014 - Gyrodontium sacchari (Spreng.) Hjortstam - a new record of wood-inhabiting hydnoid fungus from India. Journal on New Biological Reports 3, 71-74.

Index Fungorum. 2016 - http://www.indexfungorum.org/Names/Names.asp (accessed on June 10, 2016)

IUCN. 1994 - IUCN Red List Categories. Prepared by the IUCN Species Survival Commission, IUCN, Gland, Switzerland.

Karun NC, Sridhar KR. 2016 - Spatial and temporal diversity of macrofungi in the Western Ghat forests of India. Applied Ecology and Environmental Research 14, 1-21.

Kawagishi H, Zhuang C. 2008 - Compounds for dementia from Hericium erinaceum. Drugs of the Future 33, 149-155.

Ma B-J, Shen J-W, Yu H-Y, Ruan Y, Wu T-T, Zhao X, 2010 - Hericenones and erinacines: stimulators of nerve growth factor (NGF) biosynthesis in Hericium erinaceus. Mycology 1, 92-98.

Nikolajeva TL. 1950 - Acta Inst. Bod. Acad. Sci. USSR Plant. Crypt., Fasc. II 6, 222.

Park I-C, Seok S-J, Kim J-S, Yoo J-H, Ahn J-H. 2015 - Analysis of mycological characteristics and lignocellulose degradation of Gyrodontium sacchari. Korean Journal of Mycology 43, 239-246.

Persoon CH. 1794 - Neuer Versuch einer systematischen Einteilung der Schwämme.Neues Magazine für der Botanik 1, 63-138.

Robledo GL, Giorgio EM, Franco CRP, Popoff O, Decock C. 2014 - Gyrodontium sacchari (Spreng.: Fr.) Hjortstam (Boletales, Basidiomycota) in America: New records and its geographic distribution. Check List 10, 1514-1519.

Semwal KC, Stephenson SL, Bhatt VK, Bhatt RP. 2014 - Edible mushrooms of the Northwestern Himalaya, India: a study of indigenous knowledge, distribution and diversity. Mycosphere 5, 440-461.

Seok LJ, Min KM, Cho JY, Hong EK. 2009 - Study of macrophage activation and structural characteristics of purified polysaccharides from the fruiting body of Hericium erinaceus. Journal of Microbiology and Biotechnology 19, 951-959.

Thind KS, Khara HS. 1975 - The Hydnaceae of the North Western Himalayas-II. Indian Phytopathology 28, 57-65.

Thongbai B, Rapior S, Hyde KD, Wittstein K, Stadler M 2015 - Hericium erinaceus, an amazing medicinal mushroom. Mycological Progress 14, 1-23.

Valenzuela R, Raymundo T, Decock C, Esqueda M. 2012 - Aphyllophoroid fungi from Sonora, México 2. New records from Sierra de Álamos-Río Cuchujaqui Biosphere Reserve. Mycotaxon 122, 51-59.

Zutshi SK, Gupta V. 2013 - Occurrence and characterization of Hericium coralloides: a rare wild edible mushroom from Doda region of J \& K, India. Journal of Mycopathological Research 51, 361-363. 